\title{
THE IMPACT OF ECONOMIC SITUATION IN THE COUNTRIES RECEIVING MIGRANTS ON REMITTANCES FLOWS
}

\author{
Andrej Př́ivara \\ University of Economics in Bratislava, Bratislava, Slovak Republic
}

The studies on remittances focus mainly on their effects on the stability of households' incomes and/or consumption patterns. The purpose of the current paper is to highlight that the volatility of remittances can have the opposite effect. We believe that the conjuncture of the countries that receive migrants also determines their money transfers and their changes are then transmitted to the economy of the migrants' country of origin, thus increasing the instability in the latter. We believe that the volatility of remittances is higher under specific conditions, namely, when they represent a substantial part of household income and when migrants are highly concentrated in one or several countries only. Otherwise, even if one of the recipient countries is experiencing temporary economic issues, flows will be less affected since the other host countries may not be affected by such a downturn in their economy. Diversification of the diaspora is therefore crucial for the stability of remittances since the more is the number of host countries, the less likely is a sudden decline in remittances in the event of a recession in one of those countries.

Keywords: remittances; migration; volatility; labor migrants

\section{Introduction}

According to the definition presented in the Manual of Balance of Payments of the International Monetary Fund, workers' remittances commonly known as "remittances" or "migrant transfers" are transfers of goods or financial flows made by migrants who are living and working in another country, in favor of the residents of their former country of residence (IMF, 2010).

The remittances represent an important source of external finance for many developing economies. Increasing steadily for several years, these resources represent the second source of financing for developing countries after foreign direct investments (FDI) and before official development assistance (ODA). Many economists believe that the particularity of these flows is their stability. They claim that, unlike FDI, which increases during growth phases and decreases during economic depressions, remittances are less subject to economic

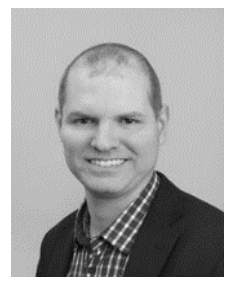

Andrej Př́ivara

PhD, Assistant Professor, Department of Social Development and Labour, University of Economics in Bratislava, Slovak Republic

Research interests: international migration, EU labor market, international regulation of labor migration.

E-mail: andrej.privara@euba.sk 


\section{THE IMPACT OF ECONOMIC SITUATION IN THE COUNTRIES}

conditions and have been increasing steadily since the 1990s, despite multiple recessions and crises that the world has seen.

Table 1 - Remittances and other flows to developing countries (in bln USD)

(Source: International Monetary Fund; UNCTAD: World Investment Report 2019. New York, 2019)

\begin{tabular}{|l|c|c|c|c|}
\hline & 1995 & 2004 & 2015 & 2019 \\
\hline Remittances & 102 & 160 & 601 & 706 \\
\hline IDE & 107 & 166 & 765 & 721 \\
\hline APD & 59 & 79 & 131 & 152 \\
\hline
\end{tabular}

The growth of these transfers is taking place due to many factors. First, the increase in the number of immigrants in the majority receiving countries has been associated with an increase in remittances. Secondly, the drop in transaction costs has undoubtedly served as an instrument to convert a large part of informal flows into official transfers. In this context, it must be said that the data in Tab. 1 concerns only the flows passing through formal circuits. In reality, it is difficult to know the exact volume and frequency of these flows, as many labour emigrants are using informal channels to send money back home. It is estimated that unofficial transfers represent at least 1.5 times of the official flows.

The current paper aims to answer the following research questions:

Are remittances really a stable source of income for the migrants' countries of origin? Are their flows not determined by the development of the economic situation in the countries receiving migrants?

\section{Literature review}

Economic literature provides many different answers regarding the impact of remittances on income stabilization and, therefore, on household consumption patterns. The authors generally agree that remittances tend to stabilize household consumption as such (Combes \& Ebeke, 2011), and this eventually results in less fluctuating GDP (Hakura., 2009). Such behavior can be explained by the altruistic motives of labour migrants who are thus showing their efforts to share the benefits from migration with their relatives who have remained in their country of origin. According to (Ratha, 2005), remittances intended for household consumption are the most stable ones since they are sent for altruistic reasons and are therefore less subject to strategic reconsiderations.

Ratha also suggests that the stabilizing potential is particularly important during the periods of recession in the countries where household income is highly dependent on remittances (Ratha, 2005, p. 161). This factor often encourages other workers to migrate too. However, this statement must be tempered because emigration is not only the result of unfavorable economic conditions in the migrants' country of origin.

The amount of remittances is not only explained by the economic situation of the migrant's country of origin since their income is often predetermined by the conditions in a host country. In other words, remittances are strongly correlated with the economic activity of the receiving countries of migrants, as shown by Ahmed (2012) on the example of the Middle East countries: sending remittances is heavily constrained by oil production, as foreign workers are employed mainly in this industry. As a result, a drop in oil or production 
prices directly affects the income of migrants and the amount of money they send back to their countries of origin. It is clear from this that rather the economic situation in a host country determines the migrants' decision about the volume of remittances rather than the conditions in their country of origin. Thus, an economic crisis affecting the volume of production in a host country of migrants can have a significant impact on the level of remittances, as it was the case during the 2008 recession.

The economic situation of a host country is less critical when remittances are sent to support households following a natural disaster in the migrant's country of origin, which is thus exposed to an external shock. In this case, the economic cycle of a host country does not matter because a natural disaster causes damage limited to a relatively small geographical area. The research results, therefore, come towards a near consensus on the remittances for this type of events. The stabilizing role of remittances in the event of a natural disaster is confirmed by the research studies carried out by Amudeo-Dorantes (2010) and Combes \& Ebeke (2011).

It turns out that the countercyclical nature, often attributed to remittances, requires that the migrant's host country and the country of origin are not in crisis at the same time, because the volume of remittances sent largely depends on the business cycle. However, the process of globalization including more and more developing countries tends to synchronize their economic cycles with those of economically developed countries (welcoming an impartial share of migrants). We consider this to be an important fact which calls attention to the question of the countercyclical aspect of remittances. This phenomenon, observed during the last global economic and financial crisis and rarely highlighted in literature (Koser, 2009, p. 9 ), contrasts with the effects of previous crises on migration. Indeed, the crises observed since the post-war period have generally affected only certain geographical areas and not the world economy. Thus, crises affecting a group of countries have been beneficial for other countries (Koser, 2009, p. 8).

\section{The concentration of the diaspora and the instability of the host country as the main determinants of volatility in remittances}

Most of the studies we cited above are based on the assumption that remittances are beneficial for the country of origin because they stabilize household consumption and economic growth, due to their countercyclical nature and the altruistic behavior of migrants. However, these same works note that the effects of remittances are not that simple: there is a certain threshold beyond which their stabilizing effect decreases. Combes \& Ebeke state in their study that the level of remittances must be very high to destabilize consumption. They explain the relatively high value of the threshold by the fact that consumption is less volatile than income, which is consistent with the theory of permanent income.

There are countries whose economic activity and household consumption are largely dependent on remittances. This is particularly the case in a large number of countries of the former USSR, where remittances sometimes reach more than $20 \%$ of GDP. Under these circumstances, it is not surprising to note that the income of migrant households (and therefore their consumption) depends to a large extent on the volume of remittances. This exposes these households to changes in the amounts transferred, which are determined by the circumstances of the countries receiving migrants. 
THE IMPACT OF ECONOMIC SITUATION IN THE COUNTRIES
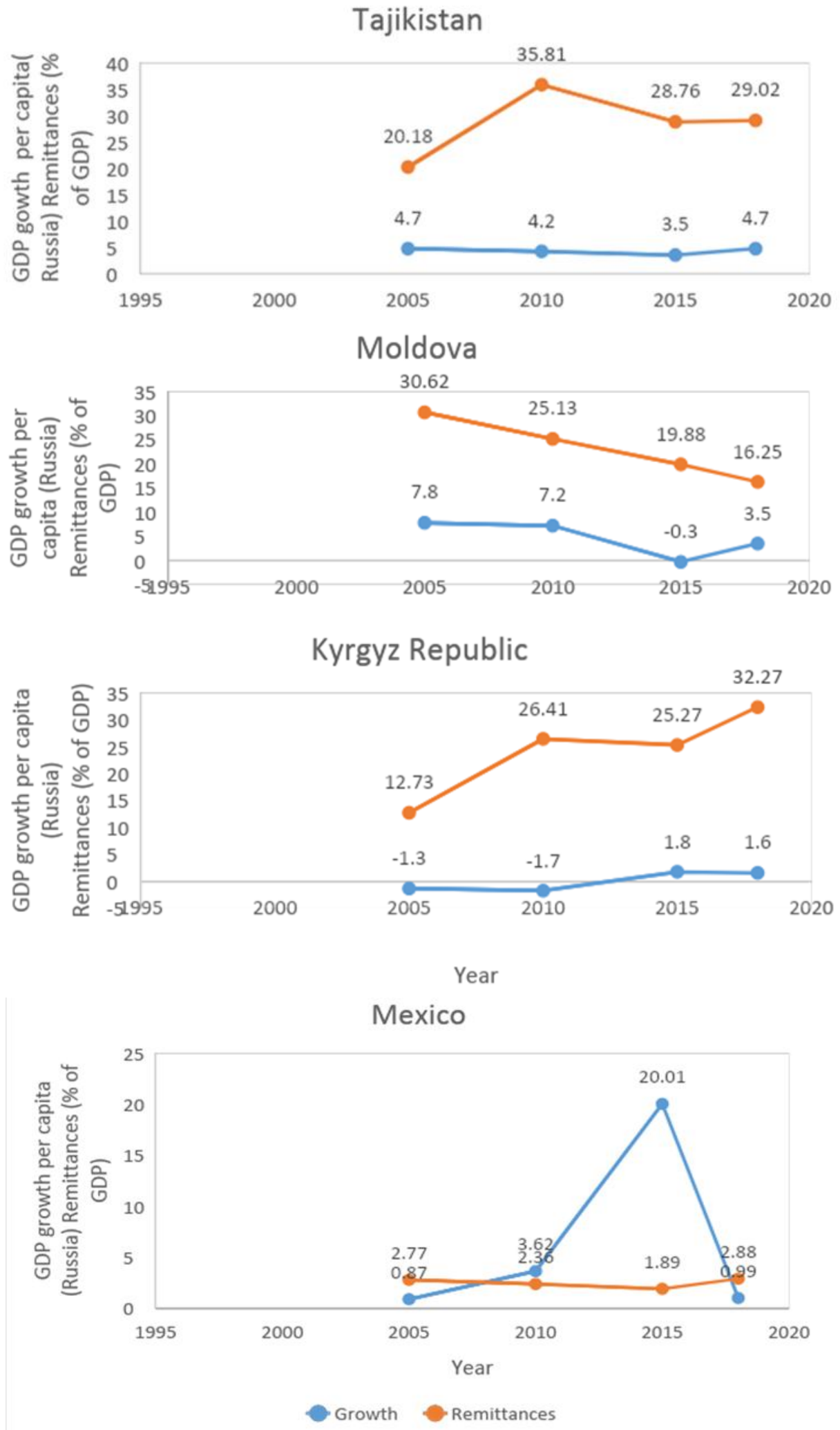

Figure 1 - Correlation between remittances and economic growth in the main destination country of migrants 
To illustrate, we present the example of 3 countries of the former USSR, whose emigrants go mainly to Russian Federation, as well as the example of Mexico, whose emigrants work mainly in the USA (see Fig. 1).

Table 2 - Correlation between remittances and economic growth in the main migrant destination country

(Source: made by the author based on data from Source: Migrations and Remittances Factbook 2019)

\begin{tabular}{|l|c|c|c|c|}
\hline Tajikistan & 2005 & 2010 & 2015 & 2018 \\
\hline $\begin{array}{l}\text { GDP growth per capita } \\
\text { (Russia) }\end{array}$ & 4.7 & 4.2 & 3.5 & 4.7 \\
\hline Remittances & 20.18 & 35.81 & 28.76 & 29.02 \\
\hline
\end{tabular}

\begin{tabular}{|l|c|c|c|c|}
\hline Moldova & 2005 & 2010 & 2015 & 2018 \\
\hline $\begin{array}{l}\text { GDP growth per capita } \\
\text { (Russia) }\end{array}$ & 7.8 & 7.2 & .0 .3 & 3.5 \\
\hline Remittances (\% of GDP) & 30.62 & 25.13 & 19.88 & 16.25 \\
\hline
\end{tabular}

\begin{tabular}{|l|c|c|c|c|}
\hline Kyrgyz Republic & 2005 & 2010 & 2015 & 2018 \\
\hline $\begin{array}{l}\text { GDP growth per capita } \\
\text { (Russia) }\end{array}$ & -1.3 & -1.7 & 1.8 & 1.6 \\
\hline Remittances (\% of GDP) & 12.73 & 26.41 & 25.27 & 32.27 \\
\hline
\end{tabular}

\begin{tabular}{|l|c|c|c|c|}
\hline Mexico & 2005 & 2010 & 2015 & 2018 \\
\hline $\begin{array}{l}\text { GDP growth per capita } \\
\text { (Russia) }\end{array}$ & 0.87 & 3.62 & 2.01 & 0.99 \\
\hline Remittances (\% of GDP) & 2.77 & 2.36 & 1.89 & 2.88 \\
\hline
\end{tabular}

Households' dependence on remittances can affect the whole economy, as those countries are used to support consumption, investment, and even monetary stability using the remittances as an important source of foreign currency inflow. The origin of remittances is decisive, as it conditions their macroeconomic impacts in the migrant's country of origin. Indeed, diaspora concentration has a significant effect on the stability of remittances: when migrants are concentrated in a small number of countries, economic change in one of these countries strongly affects the amount of money sent.

To simplify our reasoning, consider a country that receives large volumes of remittances and whose diaspora is located in a single host country. It is clear that the dependence on remittances is strong in this case since it is the conjuncture of a single country that will determine the income of migrants and therefore their ability to send money to their country of origin.

Suppose now that the diaspora of the same country is equally distributed among ten different host countries: the instability of a country will have a much smaller impact on remittances because their origin is much more diverse than in the first case.

For a migrant to be able to send remittances to his country of origin - whatever his motives are - it is necessary that he can exercise an activity generating an income in the 


\section{THE IMPACT OF ECONOMIC SITUATION IN THE COUNTRIES}

host country. Thus, it is not so much the motivations of the migrant as the economic cycle of a host country that influences the value of remittances.

We believe that the economy of the receiving countries also determines their monetary transfers and that their changes are transmitted to the economy of the country of origin of the migrants, thus increasing its instability. Such an approach takes into account two fundamental dimensions: the effect of the economic situation of host countries on remittances and the concentration of migrants in these countries.

If household income is largely made up of remittances, there is a risk that their instability will spread to the economy through consumption and/or investment. Indirectly, a country characterized by a dependence on remittances also depends on the economic situation of the country where its migrant workers are settled. On the other hand, it is clear that if the instability of host countries has repercussions on remittances, without having clear macroeconomic consequences for the country of origin of the migrant, then we can't speak of direct dependence. This is a fairly common case when the received remittances, while not being negligible, also are not vital for the economy or households.

Although they are subject to the economic cycle of the countries in which emigrants work, their fluctuations do not have the same consequences as in the case of dependency, as defined above. Likewise, a concentrated diaspora does not necessarily mean dependence if remittances account for only a small share of GDP, as in the case of Mexico, where, for example, they are subject to the economic cycle of the countries in which the emigrants work, their fluctuations do not have the same consequences as in the case of dependency, as defined above.

\section{Conclusion}

Studies on remittances mainly focus on their impact on the stability of household income and/or consumption. The purpose of our article is to highlight that the volatility of remittances can have completely opposite effects. This volatility was not taken into account since in most cases the authors study remittances in relation to the GDP of the migrant's country of origin.

Economic literature has long viewed remittances as a very stable source of capital relative to foreign direct investment and official development assistance (Ratha, 2005; Frankel, 2009).

However, the 2008-2009 economic crisis has shown that remittances are mainly determined by the economic situation of the countries from which they come from: for the first time, the World Bank statistics have recorded a drop in remittances to developing countries.

These circumstances show that remittances are sensitive to the economic conditions of host countries, but the effects of their potential instability have not been examined in literature.

However, if remittances are a source of economic growth for the benefiting countries, the positive impacts will likely result in undesirable effects during the periods of high instability, especially for the countries whose economies and households depend on this source. 


\section{Acknowledgment}

This research was funded by the Vega research project no. 1/0037/20: "New challenges and solutions for employment growth in changing socio-economic conditions" and VEGA research project no. 1/0287/19 "Integration of immigrants in the EU countries from the point of view of migration policies".

\section{References:}

Ahmed, F. (2012). The perils of unearned foreign income: Aid, remittances, and government survival. American Political Science Review, 106, 146-165.

Amuedo-Dorantes, C. (2010). Remittances in Small Island Developing States. Journal of Development Studies, 46 (5), 941-960.

Combes, J.-L. \& Ebeke, C. (2011). Remittances and household consumption instability in developing countries. World Development, 39(7), 1076-1089.

IMF (2010). Balance of Payments and International Positions Manual. International Monetary Fund, Washington, D. C.

International Monetary Fund (2019). Report ON Development. New York

Frankel, J. A. (2009). Are bilateral remittances countercyclical? NBER Working Papers 15419, National Bureau of Economic Research, Inc.

Hakura et al. (2009). Remittances and the real effective exchange rate. MPRA Paper 40084, University Library of Munich, Germany.

Koser, K. (2009). The Impact of the Global Financial Crisis on International Migration: Lessons Learned. Rapport technique 37, International Organization for Migration.

Migration and remittances factbook (2019). Available online at: www.Knoema.com.

Ratha, D. (2005). Workers remittances: An important and stable source of external development finance. Economics Seminar Series Paper 9, Cloud State University.

Paper submitted

Paper accepted for publishing

Paper published online
12 July 2020

05 October 2020

30 November 2020 